University of Nebraska - Lincoln

DigitalCommons@University of Nebraska - Lincoln

Biological Systems Engineering: Papers and

Publications

Biological Systems Engineering

$11-2011$

\title{
Design and Application of a Direct-Push Vadose Zone Gravel Permeameter
}

Ronald B. Miller

Oklahoma State University, ron.miller@okstate.edu

Derek M. Heeren

University of Nebraska-Lincoln, derek.heeren@unl.edu

Garey A. Fox

Oklahoma State University, gafox2@ncsu.edu

Daniel E. Storm

Oklahoma State University - Main Campus, dan.storm@okstate.edu

Todd Halihan

Oklahoma State University - Main Campus, todd.halihan@okstate.edu

Follow this and additional works at: https://digitalcommons.unl.edu/biosysengfacpub

Miller, Ronald B.; Heeren, Derek M.; Fox, Garey A.; Storm, Daniel E.; and Halihan, Todd, "Design and Application of a Direct-Push Vadose Zone Gravel Permeameter" (2011). Biological Systems Engineering: Papers and Publications. 318.

https://digitalcommons.unl.edu/biosysengfacpub/318

This Article is brought to you for free and open access by the Biological Systems Engineering at DigitalCommons@University of Nebraska - Lincoln. It has been accepted for inclusion in Biological Systems Engineering: Papers and Publications by an authorized administrator of DigitalCommons@University of Nebraska Lincoln. 
Published in Groundwater 49:6 (November/December 2011), pp. 920-925; doi: 10.1111/j.1745-6584.2010.00796.x

Copyright $\odot 2011$ Ronald B. Miller, Derek M. Heeren, Garey A. Fox, Daniel E. Storm, and Todd Halihan.

Published by National Ground Water Association. Used by permission.

Published online February 9, 2011.

\title{
Design and Application of a Direct-Push Vadose Zone Gravel Permeameter
}

\author{
Ronald B. Miller, ${ }^{1}$ Derek M. Heeren, ${ }^{1}$ Garey A. Fox, ${ }^{1}$ Daniel E. Storm, ${ }^{1}$ and Todd Halihan ${ }^{2}$
}

1. Department of Biosystems and Agricultural Engineering, Oklahoma State University, Stillwater, OK 74078.

2. School of Geology, Oklahoma State University, Stillwater, OK 74078.

Corresponding author - G. A. Fox, Department of Biosystems and Agricultural Engineering, Oklahoma State University, Stillwater, OK 74078; tel 405 744-8423, fax 405 744-6059, email garey.fox@okstate.edu

\begin{abstract}
A borehole permeameter is well suited for testing saturated hydraulic conductivity $\left(K_{\text {sat }}\right)$ at specific depths in the vadose zone. Most applications of the method involve fine-grained soils that allow hand auguring of test holes and require a small water reservoir to maintain a constant head. In non-cohesive gravels, hand-dug test holes are difficult to excavate, holes are prone to collapse, and large volumes of water are necessary to maintain a constant head for the duration of the test. For coarse alluvial gravels, a direct-push steel permeameter was designed to place a slotted pipe at a specific sampling depth. Measurements can be made at successive depths at the same location. A $3790 \mathrm{~L}$ (1000 gallons) trailer-mounted water tank maintained a constant head in the permeameter. Head in the portable tank was measured with a pressure transducer and flow was calculated based on a volumetric rating curve. A U.S. Bureau of Reclamation analytical method was utilized to calculate $K_{\text {sat }}$. Measurements with the permeameter at a field site were similar to those reported from falling-head tests.
\end{abstract}

\section{Introduction}

Alluvial floodplains commonly contain high conductivity gravel subsoils, which are complex depositional features that have an important role in the hydrological interaction between the stream and upland areas (Knighton 1998; Bridge 2003). Heterogeneity in these complex deposits may contribute to preferential flow within the floodplain. Fuchs et al. (2009) and Heeren et al. (2010a, 2010 b) studied preferential flow in an alluvial floodplain along the Barren Fork Creek in the Ozark eco-region of Oklahoma with gravel-dominated subsoils. Estimated saturated hydraulic conductivity $\left(K_{\text {sat }}\right)$ of the preferential flow path from falling-head tests ranged between 140 and $230 \mathrm{~m} / \mathrm{d}$ (460 to $750 \mathrm{ft} / \mathrm{d}$ ) (Fuchs et al. 2009). Subsequent geophysical surveys at the Barren Fork Creek and similar floodplains on Flint Creek and Honey Creek indicated vertical heterogeneity at the sub-meter scale, which suggested that hydraulic conductivity may vary at the same scale (Heeren et al. 2010b). Experience with installing monitoring wells at these sites showed that the non-cohesive gravel subsoils were prone to collapse and resistant to penetration. Hence, a method was designed for estimating $K_{\text {sat }}$ at specific depths in the vadose zone and within the same borehole.

Borehole permeameters are commonly employed for determining $K_{\text {sat }}$ at specific depths in the vadose zone. Borehole permeameter tests were first described by Zangar (1953) and Glover (1953), and were included in the U.S. Bureau of Reclamation (USBR) Ground Water Manual (1985). The steady state derivation by Glover (1953) assumed saturated flow within a region bounded by atmospheric pressure. Subsequent research has recognized the effects of air entrapment, partial saturation, and matric suction on measured hydraulic conductivity, and sometimes the term $K_{\mathrm{fs}}$ indicating "field saturation," is used to differentiate borehole or similar tests from tests where the soil is known to be fully saturated (Stephens et al. 1982, 1983; Elrick and Reynolds 1992; 


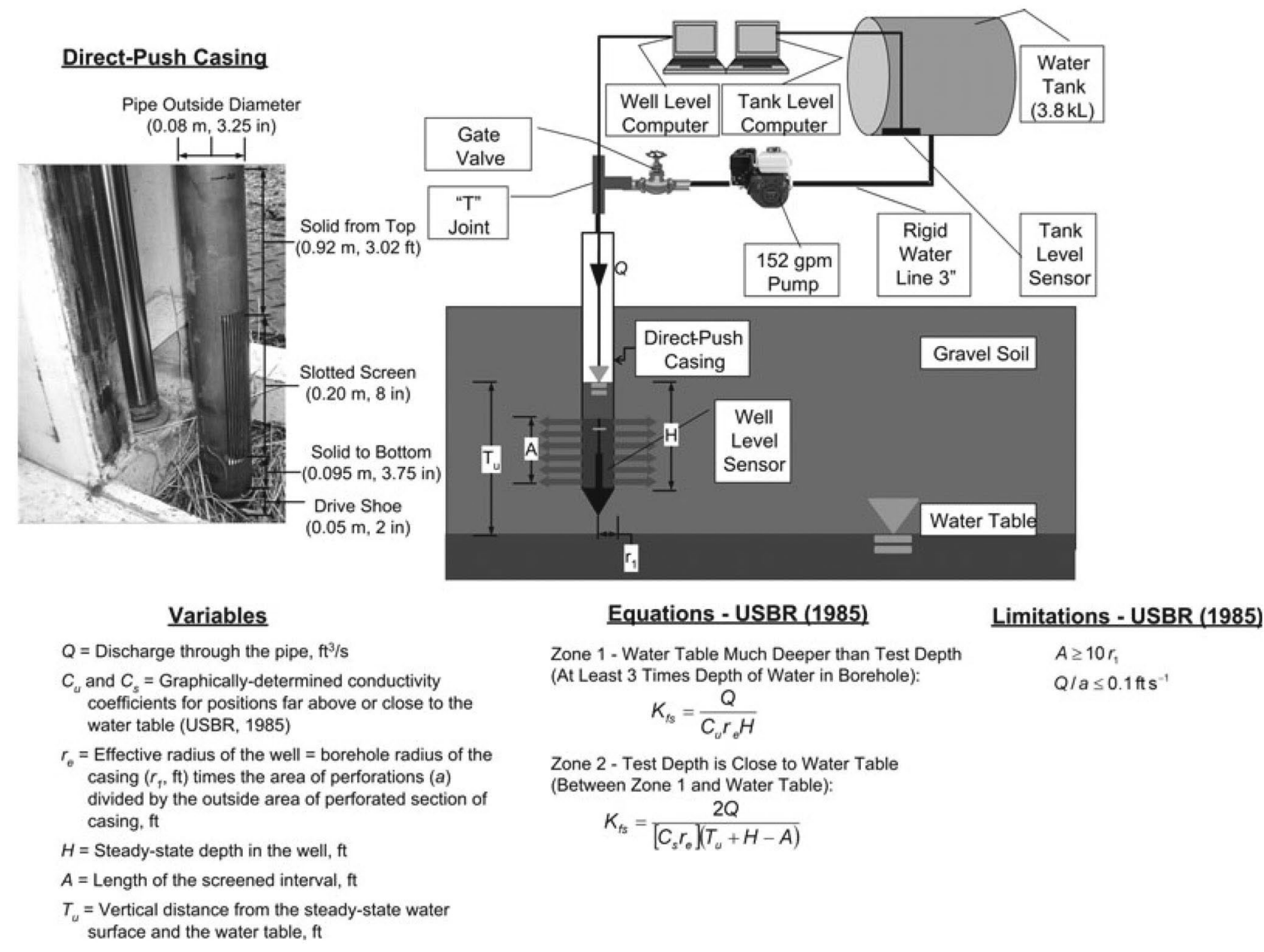

Figure 1. Configuration of gravel borehole permeameter and the USBR (1985) Gravity Permeability Test Method 3 utilized in the analysis of test results.

Cassiani 1998). In the gravel-dominated soils tested using the gravel permeameter, those effects were assumed to be insignificant, and therefore the use of the USBR (1985) Gravity Permeability Test Method 3, which neglects those effects, was justified and the results are reported as $K_{\text {sat }}$ (Stephens et al. 1982, 1983; Stephens 1995; Selker et al. 1999). Descriptions of data collection and analysis refer to this method (Figure 1). Future users will encounter unique field conditions and project requirements and should refer to Stephens (1995) for a description of the analytical methods for borehole permeameters and their data requirements.

While the analytical solutions in gravel soils are simpler, the field logistics are more challenging; gravel is difficult to penetrate, is prone to collapse in unsupported holes, and may require large volumes of water. Previously published modifications of traditional borehole permeameter tests are inadequate for such conditions. For example, Bell and Schofield (1990) designed a permeameter for high conductivity soils with the primary criterion being portability and construction from readily available materials. The $40 \mathrm{~L}$ reservoir volume could be conveniently carried by two people. Although the reservoir size was larger than other commercially available units, in highly conductive soils steady state could not be achieved before exhausting the water supply.

This research presents a design for a direct-push borehole permeameter capable of performing adequately in gravel-dominated soils. Design criteria included the following: (1) the ability to withstand the force needed to penetrate the gravel subsoil, (2) capacity to provide support against collapse of the formation, (3) capacity to provide a water supply sufficient to achieve steady state and maintain a constant head for a suitable test duration, and (4) capacity to estimate $K_{\text {sat }}$ for discrete depth intervals, even within the same borehole, in the vadose zone of a heterogeneous gravel formation.

\section{Methodology}

The permeameter consisted of a screened direct-push pipe, a trailer-mounted water reservoir, and measurement instrumentation. A standard $48 \times 3.25$ inches $(1.22$ $\times 0.082 \mathrm{~m}$ ) section of Geoprobe Systems (Kejr Inc., Salina, Kansas) direct-push pipe, with a 0.3 inch $(7.9 \mathrm{~mm})$ wall thickness, was modified to create a screen by cutting 27 vertical slots $0.002 \mathrm{~m}$ ( $0.07 \mathrm{inch})$ wide by 0.203 $\mathrm{m}$ (8 inches) long arranged in three groups around the pipe perimeter and separated by solid (unslotted) areas 
(Figure 1). The three-section slot arrangement provided a compromise between the uniform perforation pattern recommended by USBR (1985) and adequate strength to safely penetrate gravels. Screen length was adopted for hydraulic testing within a $25 \mathrm{~cm}$ (9.8 inches) depth interval defined by site geophysical testing; future users could create a screen section of any length, limited only by the overall pipe length. Alternate slot arrangements may provide more uniform flow into the formation while maintaining sufficient driving strength. Please note that the pipe was modified without authorization from Geoprobe Systems and the responsibility for any modification is that of the user.

Total screened area of the modified pipe (hereafter the permeameter) was $0.01 \mathrm{~m}^{2}\left(0.12 \mathrm{feet}^{2}\right)$ with a ratio of open to total area of $21 \%$. After adding a solid drive shoe, the permeameter was lengthened to reach specified depths by threading on unmodified pipe sections. A Geoprobe 6200 TMP (Trailer-Mounted Probe) with a direct-push force of $142 \mathrm{kN}$ augmented with a $32 \mathrm{~Hz}$ pneumatic hammer positioned the permeameter at selected depths. Although driving a permeameter can cause "smearing" in fine-grained soils and artificially reduce the measured $K_{\text {sat }}$ smearing was likely not a problem in the gravel subsoils (Bell et al. 1990). However, driving the permeameter caused an unknown amount of compaction, rotation and breakage of gravels, and possibly the creation of a zone of increased conductivity around the permeameter (USBR 1985). This was assumed analogous to a gravel pack surrounding a developed well and negligible in the final analysis if the flow volume and steady-state period sufficiently saturated the undisturbed formation. Although acknowledged to be the least accurate of similar tests, Method 3 is the only test applicable for the gravel permeameter, and when carefully performed it is assumed to provide results within an order of magnitude of the true value (Ahrens et al. 1951). Vadose zone measurements could represent vertical averages of the horizontal conductivity of multiple strata and vertical flow (not characterized by the method) could also be relevant in such applications.

The reservoir system was a $3.79 \mathrm{~m}^{3}\left(10^{3}\right.$ gallons) portable water tank (Wako Inc., Enid, Oklahoma) for which a stage/volume relationship was determined. The water tank was plumbed to the permeameter through a $5 \mathrm{~cm}$ (2.0 inches) diameter suction hose inserted into the permeameter with an in-line $0.1 \mathrm{~m}^{3} / \mathrm{s}$ (152 gpm) gasoline-powered water pump (American Honda, Alpharetta, Georgia). Permeameter flow was controlled with a 5-cm (2.0 inches) brass gate valve. Head in the tank and permeameter were monitored at 1-s intervals with vented pressure transducers (In-Situ Inc., Fort Collins, Colorado) (Figure 1). The in-line pump was able to produce a maximum discharge through the screen of $0.01 \mathrm{~m}^{3} / \mathrm{s}$ (152 gpm).

Test setup involved driving the permeameter to the selected depth, connecting the water supply, and directing water into the permeameter. The permeameter screen was cleaned with a $7.5 \mathrm{~cm}$ (2.95 inches) nylon brush on an extendable handle and the debris removed with a peristaltic pump. The transducer was placed in the permeameter and flow was adjusted to bring the head in the well to the desired elevation. Testing was initiated after the transducers registered an approximately constant head with a constant flow rate, usually after 10 to $15 \mathrm{~min}$. Test durations were approximately 15 min. Data collected included the head in the permeameter $(H$, datum at base of permeameter screen) and the tank water level. Flow into the well $\left(Q, \mathrm{~m}^{3} / \mathrm{s}\right)$ was calculated using the tank's stage/volume relationship and the steady-state elapsed time. After the test, the transducer and water supply were removed and the permeameter repositioned for the next test. Repositioning sometimes included driving the permeameter deeper into the borehole, resulting in a $K_{\text {sat }}$ depth profile, usually accomplished in $15 \mathrm{~min}$. Driving to greater depths than the length of the screened pipe section was accomplished by threading on additional unscreened pipe. Positioning the permeameter at a new location could take an hour depending on the amount of equipment (i.e., water trailer) to be moved.

An essential element of a borehole permeameter is the ability to measure and maintain a constant $H$ (Figure 1). The USBR (1985) method recommended a permeameter diameter of at least $15.25 \mathrm{~cm}$ (6 inches) to accommodate a float mechanism to maintain a constant head for a sufficient time to achieve steady-state flow. The $7.5-\mathrm{cm}$ (2.95-inches) inner diameter of the Geoprobe pipe was too narrow for a float, so steady state was maintained remotely by manually manipulating a gate valve while monitoring $H$. Water was allowed to flow into the permeameter and the gate valve adjusted until $H$ approached the target height. After $H$ in the permeameter was steady (usually after 10 to $15 \mathrm{~min}$ ), the test was initiated by recording output from the permeameter and water tank pressure transducers for 15 to $20 \mathrm{~min}$. Total time for testing included 1 to $2 \mathrm{~h}$ for initial equipment positioning and setup and less than an hour for each test.

Note that in some cases, the zone of the permeameter below the slotted section may create an annular space, allowing flow from the slots along the outside of the pipe. When assured of the occurrence of such an annular space, users could account for the change in the effective length of the test and screened intervals. In this research, the unconsolidated gravel aquifer contained smaller gravel and finer sediment (Heeren et al. 2010b) that may have refilled this space while driving the permeameter, especially since the direct-push method required a pneumatic hammer. Therefore, an annular space below the slotted section was not considered.

\section{Results and Discussion}

The floodplain's gravel subsoil could be extremely hydraulically conductive. Measured $K_{\text {sat }}$ ranged from 2 to $183 \mathrm{~m} / \mathrm{d}(6.6$ and $600 \mathrm{ft} / \mathrm{d})$ (Table 1), with the latter an order of magnitude higher than the maximum $K_{\text {sat }}$ quantified by the permeameter designed by Bell and 
Table 1. Gravel Permeameter Measured Values and Calculated Results Including Successive Depths at Single Test Location

\begin{tabular}{lcccccccccccc}
\hline Site & $\begin{array}{c}\text { Depth }^{1} \\
(\mathrm{~m})\end{array}$ & $\begin{array}{c}\mathrm{Time}^{2} \\
(\mathrm{~min})\end{array}$ & $\begin{array}{c}Q^{3} \\
\left(\mathrm{~m}^{3} / \mathrm{min}\right)\end{array}$ & $\begin{array}{c}Q \\
(\mathrm{ft} / \mathrm{s})\end{array}$ & $\begin{array}{c}H^{4} \\
(\mathrm{~m})\end{array}$ & $\begin{array}{c}H \\
(\mathrm{ft})\end{array}$ & $Z_{\text {Zne }}^{5}$ & $T_{u}^{5}$ & $C_{u}^{5}$ & $C_{S}^{5}$ & $\begin{array}{c}K_{\text {sat }}^{6} \\
\left(10^{-3} \mathrm{ft} / \mathrm{s}\right)\end{array}$ & $\begin{array}{c}K_{\text {sat }} \\
(\mathrm{m} / \mathrm{d})\end{array}$ \\
\hline $\mathrm{BF10}^{7}$ & 2.01 & 33.17 & 0.016 & 0.009 & 0.30 & 0.98 & 1 & 3.6 & 60 & & 5.6 & 146 \\
$\mathrm{BF10}^{8}$ & 2.46 & 24.05 & 0.010 & 0.006 & 0.29 & 0.94 & 2 & 2.1 & & 43 & 3.7 & 96 \\
$\mathrm{BF8}^{7}$ & 1.27 & 24.67 & 0.006 & 0.004 & 0.26 & 0.85 & 1 & 5.7 & 55 & & 2.8 & 73 \\
$\mathrm{BF8}^{8}$ & 1.72 & 21.58 & 0.019 & 0.011 & 0.26 & 0.86 & 1 & 4.3 & 67 & & 6.8 & 180 \\
$\mathrm{BF1}$ & 2.01 & 19.23 & 0.020 & 0.012 & 1.91 & 6.26 & 2 & 8.9 & & 43 & 1.2 & 32 \\
$\mathrm{FL5}$ & 1.18 & 18.00 & 0.004 & 0.002 & 0.50 & 1.63 & 2 & 2.2 & & 43 & 1.1 & 30 \\
$\mathrm{FL8}$ & 0.44 & 20.50 & 0.004 & 0.002 & 0.39 & 1.26 & 1 & 4.8 & 65 & & 0.6 & 16 \\
$\mathrm{HC3}$ & 1.58 & 23.93 & 0.021 & 0.012 & 0.50 & 1.63 & 2 & 2.6 & & 43 & 5.1 & 134 \\
$\mathrm{HC6}$ & 1.57 & 7.00 & 0.002 & 0.001 & 1.99 & 6.52 & 1 & 10.9 & 75 & & 0.1 & 2 \\
\hline
\end{tabular}

$\mathrm{BF}=$ Barren Fork Creek; FL = Flint Creek; HC = Honey Creek.

1. Distance below ground surface to bottom of screen.

2. Duration of steady-state test.

3. Flow into permeameter at steady state.

4. Average height of water in permeameter above base of screen, corrected for free space below the base of the screen.

5. See Figure 1 for variable explanation (USBR 1985).

6. Estimated using USBR Method 3 (1985).

7,8. Indicates a single-hole depth sequence.

Schofield (1990). At the field site described by Fuchs et al. (2009), one borehole permeameter test maintained a flow of approximately $0.0044 \mathrm{~m}^{3} / \mathrm{s}\left(0.154 \mathrm{ft}^{3} / \mathrm{s}\right)$ for 12 min with a constant head of only $1.7 \mathrm{~m}$ (5.6 feet), producing a calculated $K_{\text {sat }}$ of $488 \mathrm{~m} / \mathrm{d}(1601 \mathrm{ft} / \mathrm{d})$. Such high conductivities sometimes proved problematic for the selected analytical method. According to USBR (1985), the $Q / a$ ratio is the discharge of water into the permeameter $(Q)$ divided by the screen area $(a)$, producing a mean screen velocity. Ahrens et al. (1951) estimated $0.1 \mathrm{ft} / \mathrm{s}(0.03 \mathrm{~m} / \mathrm{s})$ as an upper limit for laminar flow, and further suggested that ratios above this threshold underestimate $K_{\text {sat }}$. With $a$ equal to $0.12 \mathrm{ft}^{2}$ $\left(0.01 \mathrm{~m}^{2}\right)$ for the gravel permeameter, the $\mathrm{Q} / \mathrm{a}$ for the high flow test was $1.3 \mathrm{ft} / \mathrm{s}(0.4 \mathrm{~m} / \mathrm{s})$ and likely included non-laminar flow, but served to demonstrate the required high water volume capacity. Previous estimates of $K_{\text {sat }}$ by Fuchs et al. (2009) derived from falling-head tests ranged from 140 to $230 \mathrm{~m} / \mathrm{d}(460$ to $750 \mathrm{ft} / \mathrm{d})$, similar to the maximum $K_{\text {sat }}$ calculated with the gravel permeameter (Table 1).

The permeameter was evaluated on how well it maintained a constant $H$ with a constant $Q$. The USBR (1985) method defined steady state as

three or more measurements [at 5 minute intervals] ... within plus or minus $0.2 \mathrm{ft}(6.1 \mathrm{~cm})$

for a test section length $(A)$ of $5 \mathrm{ft}(1.52 \mathrm{~m})$, which creates a ratio of 0.04 between the allowable deviation and $A$. Whereas the USBR (1985) methods generally use an open test hole ( $H$ equals $A$ ), the permeameter was intended to determine $K_{\text {sat }}$ of a small thickness of vadose zone sediment and has a fixed $A$ of $20 \mathrm{~cm}$ (8 inches) while $H$ varied (Figure 1 ). The permeameter also utilized pressure transducers that recorded $H$ at 1-s inter- vals, yielding more measurements than the 5-min interval suggested by the USBR method. For steady state, $H$ was allowed to vary \pm 0.04 of the mean $H$ over the test (15 to $20 \mathrm{~min}$ ) with the criteria that $80 \%$ of the measurements must fall within this length interval (Figure 2). The magnitude of this allowable deviation should be acceptable considering that $K_{\mathrm{sat}}$ ranges by several orders of magnitude. Manually manipulating the gate valve maintained $H$ within the $\pm 4 \%$ range an average of $96 \%$ of the time for test intervals that averaged 16 min (Table 1). Two typical tests show that $H$ can be considered at steady state for the given criterion (Figure 2).

Permeameter flow was gauged by the pressure transducer within the water tank. In the first example (Figure 2a), the steady decline of the water level indicated that constant $H$ was produced by steady flow into the well. The $Q$ resulted in an estimated $K_{\text {sat }}$ of $180 \mathrm{~m} / \mathrm{d}(590$ $\mathrm{ft} / \mathrm{d}$ ). Example calculations are shown in the Supporting Information. The second example (Figure $2 b$ ) shows an incremental drop ( $2 \mathrm{~cm}, 0.79$ inch) in the tank water level over 20.5 min produced by the minimum detectable $Q$; the calculated $K_{\text {sat }}$ of $16 \mathrm{~m} / \mathrm{d}(52 \mathrm{ft} / \mathrm{d})$ was close to the minimum for the method.

\section{Conclusions}

The standard borehole permeameter, a principal method for estimating hydraulic conductivity in the vadose zone, is poorly suited for gravel-dominated soils. Non-cohesive and highly penetration-resistant soils presented problems overcome by devising a permeameter that employed a slotted section of a Geoprobe pushprobe pipe and a trailer-mounted tank. Unavoidable displacement or compaction of gravel may have introduced an unknown amount of uncertainty in the results. The narrow diameter of the pipe prevented the 
(a)

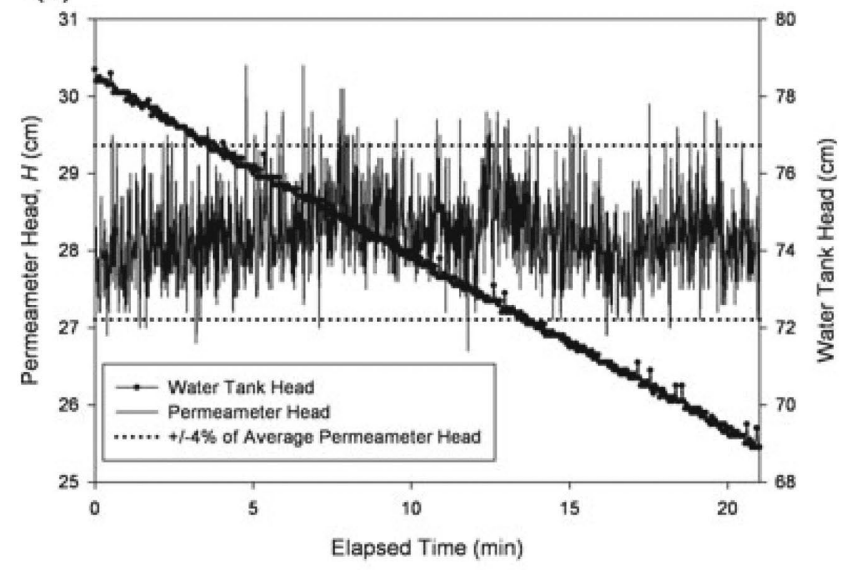

(b)

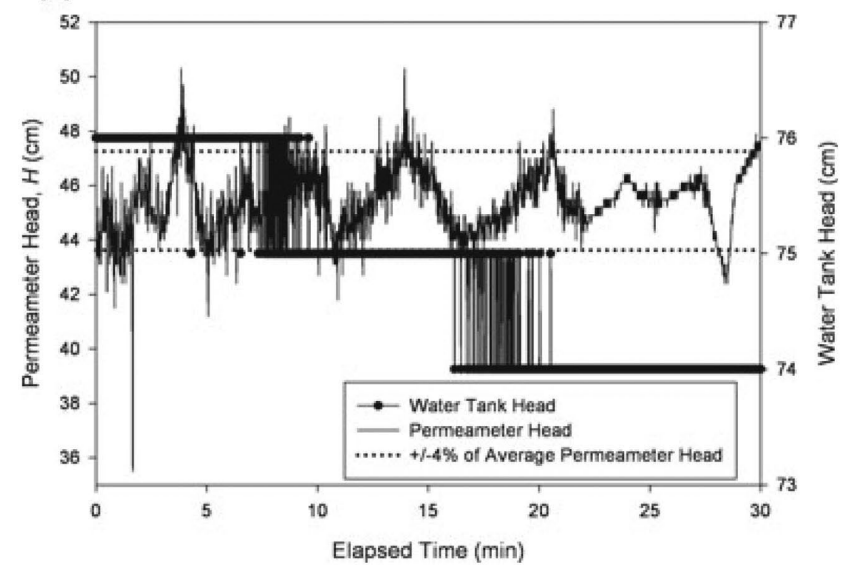

Figure 2. Constant head and tank drawdown time plots for the tests (a) BF8 and (b) FL8 described in Table 1. Solid lines with bullets indicate water level decline in the water tank. Solid lines indicate the average head $(H)$ in the permeameter and dashed lines indicate $4 \%$ of $H$. Constant head measurements from the pressure transducer include the $2 \mathrm{~cm}$ ( $0.8 \mathrm{inch})$ below the base of the screen.

use of a float-style leveler, but real-time head readings from a pressure transducer and manual manipulation of a gate valve provided sufficient control to maintain constant head in the permeameter. Previous methods exhausted available water supplies before steady state was established and maintained for sufficient time, but the large water supply from the portable tank allowed high-volume flow testing over appropriate test durations. The method provided hydraulic conductivity estimates ranging between 2 and $180 \mathrm{~m} / \mathrm{d}(6$ and $590 \mathrm{ft} / \mathrm{d})$ for targeted depths in the vadose zone, including successive depth measurements within the same borehole. Future users may modify the design of the screen to optimize the performance and select alternative analytical methods.
Acknowledgments - The authors acknowledge funding from the Oklahoma Conservation Commission through a U.S. Environmental Protection Agency Region VI 319 grant. The authors also acknowledge Aaron Mittelstet and Tim Sickbert, Oklahoma State University (OSU), for assistance in the field; Wayne Kiner and the Biosystems and Agricultural Engineering Laboratory staff at OSU for fabricating the permeameter; and Amanda K. Fox, Geoff Bohling, and two anonymous reviewers for constructive review comments.

\section{Supporting Information}

Additional Supporting Information may be found following the References: An example calculation of the saturated hydraulic conductivity using the direct-push vadose zone permeameter is shown. This example corresponds to the data for test BF8 in Table 1 shown in Figure 2a.

\section{References}

Ahrens, T.P., and A.C. Barlow. 1951. Permeability tests using drill holes and wells. U.S. Bureau of Reclamation Geology Report No. G-97, U.S. Department of the Interior, Denver, Colorado.

Bell, R.W., and N.J. Schofield. 1990. Design and application of a constant head well permeameter for shallow high saturated hydraulic conductivity soils. Hydrological Processes 4, no. 4: 327-342.

Bridge, J.S. 2003. Rivers and Floodplains: Forms, Processes, and Sedimentary Record. Oxford, UK: Blackwell Publishing.

Cassiani, G. 1998. A new method for the interpretation of the constant-head well permeameter. Journal of Hydrology 210, no. 1-4: 11-20.

Elrick, D.E., and W.D. Reynolds. 1992. Methods for analyzing constant-head well permeameter data. Soil Science Society of America Journal 56, no. 1: 320-323.

Fuchs, J.W., G.A. Fox, D.E. Storm, C. Penn, and G.O. Brown. 2009. Subsurface transport of phosphorus in riparian floodplains: Influence of preferential flow paths. Journal of Environmental Quality 38, no. 2: 473-484.

Glover, R.E. 1953. Flow from a test hole located above groundwater level. In Theory and Problems of Water Percolation, ed. C.N. Zanger, App. B. Engineering Monograph 8. U.S. Bureau of Reclamation.

Heeren, D.M., R.B. Miller, G.A. Fox, D.E. Storm, A.K. Fox, and A.R. Mittelstet. 2010a. Impact of preferential flow paths on stream and alluvial groundwater interaction. In Proceedings of the ASCE EWRI World Environmental and Water Resources Congress. Reston, Virginia: American Society of Civil Engineers.

Heeren, D.M., R.B. Miller, G.A. Fox, D.E. Storm, C.J. Penn, and T. Halihan. 2010b. Preferential flow path effects on subsurface contaminant transport in alluvial floodplains. Transactions of the ASABE 53, no. 1: 127-136.

Knighton, D. 1998. Fluvial Forms and Processes: A New Perspective. London: Arnold.

Selker, J.S., C.K. Keller, and J.T. McCord. 1999. Vadose Zone Processes. Boca Raton, FL: CRC Lewis Publishers. 
Stephens, D.B. 1995. Vadose Zone Hydrology. Boca Raton, Florida: CRC Lewis Publishers.

Stephens, D.B., S. Tyler, K. Lambert, D. Watson, R. Rabold, R. Knowlton, E. Byers, S. Yates, and S.P. Neuman. 1983. In situ determination of hydraulic conductivity in the vadose zone using borehole infiltration tests. Technical Completion Report 1423648. New Mexico Water Resources Research Institute.

Stephens, D.B., and S.P. Neuman. 1982. Vadose zone permeability tests: Steady state results. Journal of the Hydraulics Division, ASCE 108, no. HY5: 640-658.
U.S. Bureau of Reclamation (USBR). 1985. Ground Water Manual: A Water Resources Technical Manual. Revised Reprint. Denver, Colorado: U.S. Department of the Interior, Bureau of Reclamation.

Zangar, C.N. 1953. Theory and problems of water percolation, Engineering Monograph 8. U.S. Bureau of Reclamation. 
Example saturated hydraulic conductivity $\left(K_{\text {sat }}\right)$ calculation for test BF8 (shown in Figure 2a and Table 1). Note that field measurements made in SI units were reported in standard units for calculations as described by USBR Gravity Permeability Method 3 (1985).

\section{Field Data:}

Mean of depth measurements in permeameter, $H^{*}(\mathrm{ft})$

Elapsed time of test @ steady state, $t$ (min)

Stage in tank at beginning of test, $d_{\text {start }}(\mathrm{m})$

Stage in tank at end of test, $d_{\text {end }}(\mathrm{m})$

Distance from ground surface to water table, $U(\mathrm{ft})$

9.06

Distance from ground surface to bottom of permeameter screen, $D(\mathrm{ft})$

5.65

* This value has been adjusted by subtracting $0.02 \mathrm{~m}(0.066 \mathrm{ft})$ to account for the position of the pressure transducer below the permeameter screen.

Constant values:

Length of permeameter screen, $A$ (ft) 0.67

Radius of casing, $r_{l}(\mathrm{ft})$

Area of open screen, $a\left(\mathrm{ft}^{2}\right)$

Area of screened length, $a_{A}\left(\mathrm{ft}^{2}\right)$

Zone [dimensionless] ${ }^{*}$

Conductivity coefficient, $C_{u}$ [dimensionless $]^{\dagger}$

67

*From USBR (1985) - Figure 17-6.

${ }^{\dagger}$ From USBR (1985) - Figure 17-7.

\section{Calculations:}

Effective radius, $r_{e}(\mathrm{ft})$ - compensates for the reduction in flow caused by the screen:

$$
r_{e}=\frac{a}{a_{A}} r=\frac{0.12 f t}{0.57 f t}(0.135 f t)=0.028 f t
$$

Flow, $Q\left(\mathrm{ft}^{3} \mathrm{~s}^{-1}\right)$ - calculated using calibrated stage/volume relationship for tank, $V(d)$, and the test time $(t)$ :

$$
Q=\frac{V\left(d_{\text {start }}\right)-V\left(d_{\text {end }}\right)}{t}=\frac{0.413 \mathrm{~m}^{3}}{21.6 \mathrm{~min}}=0.019 \mathrm{~m}^{3} / \mathrm{min}=0.011 \mathrm{ft}^{3} / \mathrm{s}
$$

Saturated Hydraulic Conductivity, $K_{\text {sat }}$ :

$$
K_{s a t}=\frac{Q}{C_{u} r_{e} H}=\frac{0.011^{f t^{3}} / \mathrm{s}}{67(0.028 f t)(0.86 f t)}=0.0068 \mathrm{ft} / \mathrm{s}=180 \mathrm{~m} / \mathrm{d}
$$

